\title{
Giant hepatic hemangioma causing prolonged fever and indicated for resection
}

\author{
Chihiro Yoshimizu ${ }^{1}$, Shunichi Ariizumi ${ }^{2}$, Tomomi Kogiso ${ }^{1}$, Takaomi Sagawa ${ }^{1}$, \\ Makiko Taniai ${ }^{1}$, Goro Honda ${ }^{2}$, Hiroto Egawa ${ }^{2}$ and Katsutoshi Tokushige ${ }^{1}$
}

\begin{abstract}
:
Hepatic hemangiomas are benign liver tumors, and most of them progress asymptomatically. We report a case of hepatic hemangioma considered the cause of fever. A 53-year-old woman had a fever of $40^{\circ} \mathrm{C}$ for about 3 months without infection. Hepatic hemangiomas with internal bleeding of $10 \mathrm{~cm}$ in size on liver S8/7 and S3/2 were observed. These were resected laparoscopically for diagnostic treatment. She was afebrile after the operation. The pathological diagnosis was hematoma inside cavernous hemangioma. It should be noted that a bleeding hepatic hemangioma may cause fever of unknown origin and be indicated for resection.
\end{abstract}

Key words: giant hepatic cavernous hemangioma, fever of unknown origin (FUO), hepatectomy

(Intern Med Advance Publication)

(DOI: 10.2169/internalmedicine.8405-21)

\section{Introduction}

Hepatic hemangiomas are common benign liver tumors, and most of them progress asymptomatically $(1,2)$. These tumors are present in $0.4-20 \%$ of the general population (2). They are blood-filled cavities within the liver parenchyma lined by endothelial cells supplied by a branch of hepatic artery $(3,4)$. Hepatic hemangiomas are predominantly observed in females (5). They are diagnosed at all ages and the mean age of presentation is 30 to 50 years (2). The pathological development of hemangioma is suspected to relate to congenital factors, abnormal vasculogenesis, and hormonal factors (estrogen) (6). The definition of giant hemangioma in some studies is a size $>4 \mathrm{~cm}$ but $>5 \mathrm{~cm}$ or even $>10 \mathrm{~cm}$ in others $(2,3,7)$. The major complications of giant hemangioma are abdominal pain, nausea, vomiting, jaundice, and spontaneous or traumatic rupture (5). Fever of unknown origin (FUO) is not a typical symptom of hemangioma.

FUO is defined as fever $\geq 101^{\circ} \mathrm{F}\left(38.3^{\circ} \mathrm{C}\right)$ for $\geq 3$ weeks (8). Antibiotic treatment is often tried, and other common causes including infection, neoplastic/malignant, rheumatic/inflammatory, and miscellaneous disorders should be excluded. Schumacker et al. (9) in 1942 described he- patic hemangioma presenting as FUO, and 1 of 66 surgically treated liver hemangioma patients had fever.

We report a case of hepatic hemangioma considered the cause of a prolonged fever. This study was conducted in accordance with the principles of the Declaration of Helsinki and the ethical guidelines of Tokyo Women's Medical University Hospital (Tokyo, Japan).

\section{Case Report}

A 53-year-old woman had a fever of $40^{\circ} \mathrm{C}\left(104^{\circ} \mathrm{F}\right)$ during an outpatient visit to our hospital due to follow-up for Sjögren syndrome. She was not on medication or hormonal therapy, and had no history of pill use. A $3 \mathrm{~cm}$ hemangioma in $\mathrm{S} 5 / 8$ of the liver was discovered 16 years prior, however, it was not followed up. The blood examination at visit to our hospital with fever showed total protein, $8.3 \mathrm{~g} / \mathrm{dL}$; albumin, $3.3 \mathrm{~g} / \mathrm{dL}$; total bilirubin, $0.9 \mathrm{mg} / \mathrm{dL}$; aspartate aminotransferase (AST), $27 \mathrm{U} / \mathrm{L}$; alanine aminotransferase (ALT), $20 \mathrm{U} / \mathrm{L}$; alkaline phosphatase (ALP), $245 \mathrm{U} / \mathrm{L}$; gamma-glutamyl transferase (GGT), $78 \mathrm{U} / \mathrm{L}$; platelet count, $34.1 \times 10^{4} / \mu \mathrm{L}$; and prothrombin time, $100 \%$. Thus, liver functions were almost normal. Inflammatory markers including white blood cells (WBCs) $6,900 / \mu \mathrm{L}$ and $\mathrm{C}$ reactive protein

${ }^{1}$ Institute of Gastroenterology, Department of Internal Medicine, Tokyo Women's Medical University, Japan and ${ }^{2}$ Institute of Gastroenterology, Department of surgery, Tokyo Women's Medical University, Japan

Received: July 26, 2021; Accepted: October 5, 2021; Advance Publication by J-STAGE: November 20, 2021

Correspondence to Dr. Tomomi Kogiso, kogiso.tomomi@twmu.ac.jp 
a)

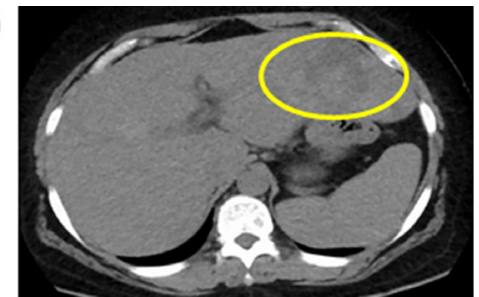

c)
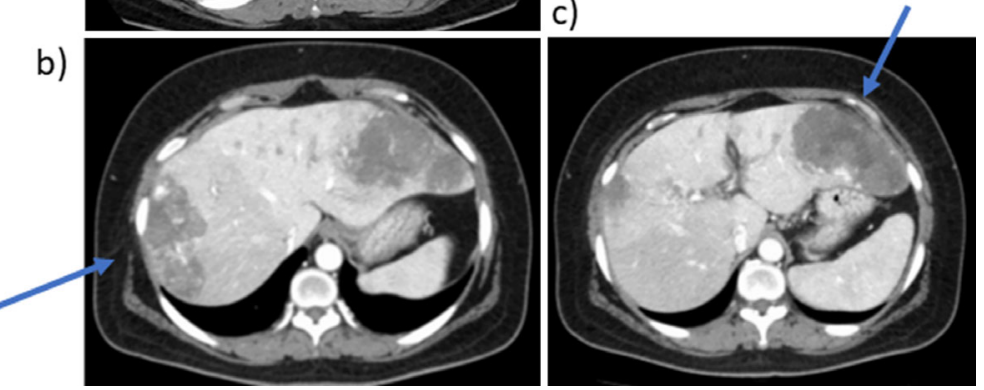

Figure 1. Abdominal CT findings. a) Plain CT, b), c) late phase of enhanced CT. Plain CT of the abdomen showed slightly high intensity inside the mass (a, circle). Hepatic masses of $10 \mathrm{~cm}$ in size in liver S8/7 (b) and S3/2 (c) with prolonged enhancement suggesting hepatic hemangiomas (arrows). Imaging examination revealed no other abnormalities. CT: computed tomography

a)

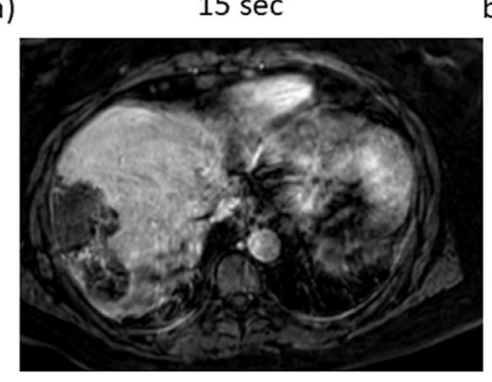

c)

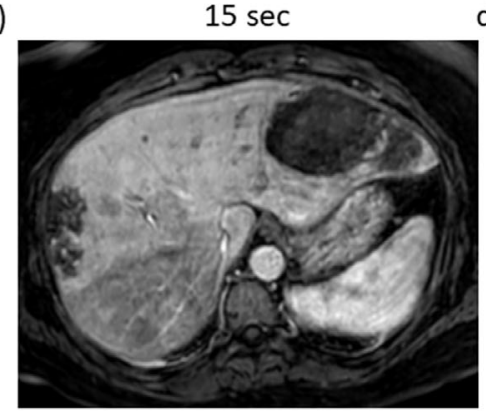

e)

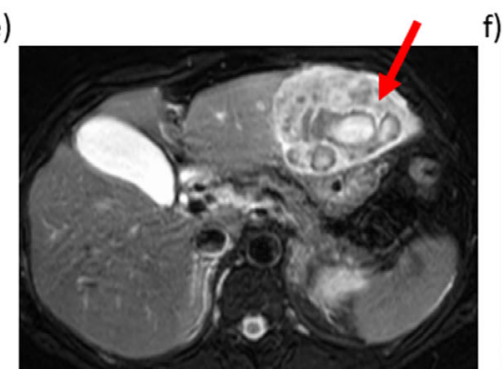

b)

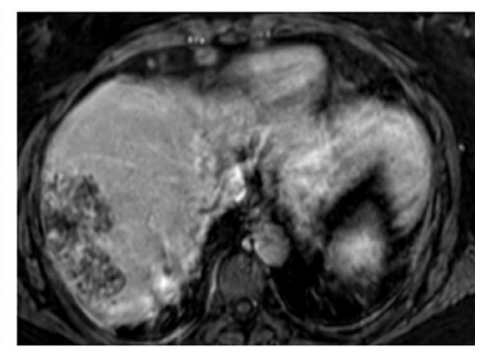

d)

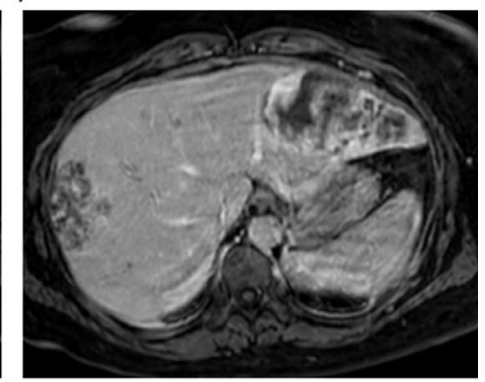

f)

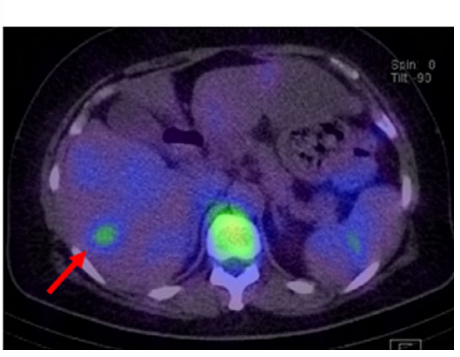

Figure 2. Abdominal MRI and gadolinium scintigraphy findings. T1 weighted-enhanced images of the right lobe after a) $15 \mathrm{~s}$ and b) $180 \mathrm{~s}$, and of the left lobe after c) $15 \mathrm{~s}$ and d) $180 \mathrm{~s}$. T2 weightedenhanced image of the left lobe. Masses in S8/7 (a, b) and S3/2 (c, d) were low intensity in T1 weightedenhanced MRI, and revealed peripheral nodular enhancement after gadolinium ethoxybenzyl diethlenetriamine pentaacetic acid administration. It consisted of a fine honeycomb-like septum inside hemangioma in S8/7. Hepatic bleeding was suspected inside the mass in S3/2 on a T2 weighted-enhanced image (e, arrow). Gadolinium scintigraphy showed slightly positive in the right lobe (f, arrow). MRI: magnetic resonance imaging 


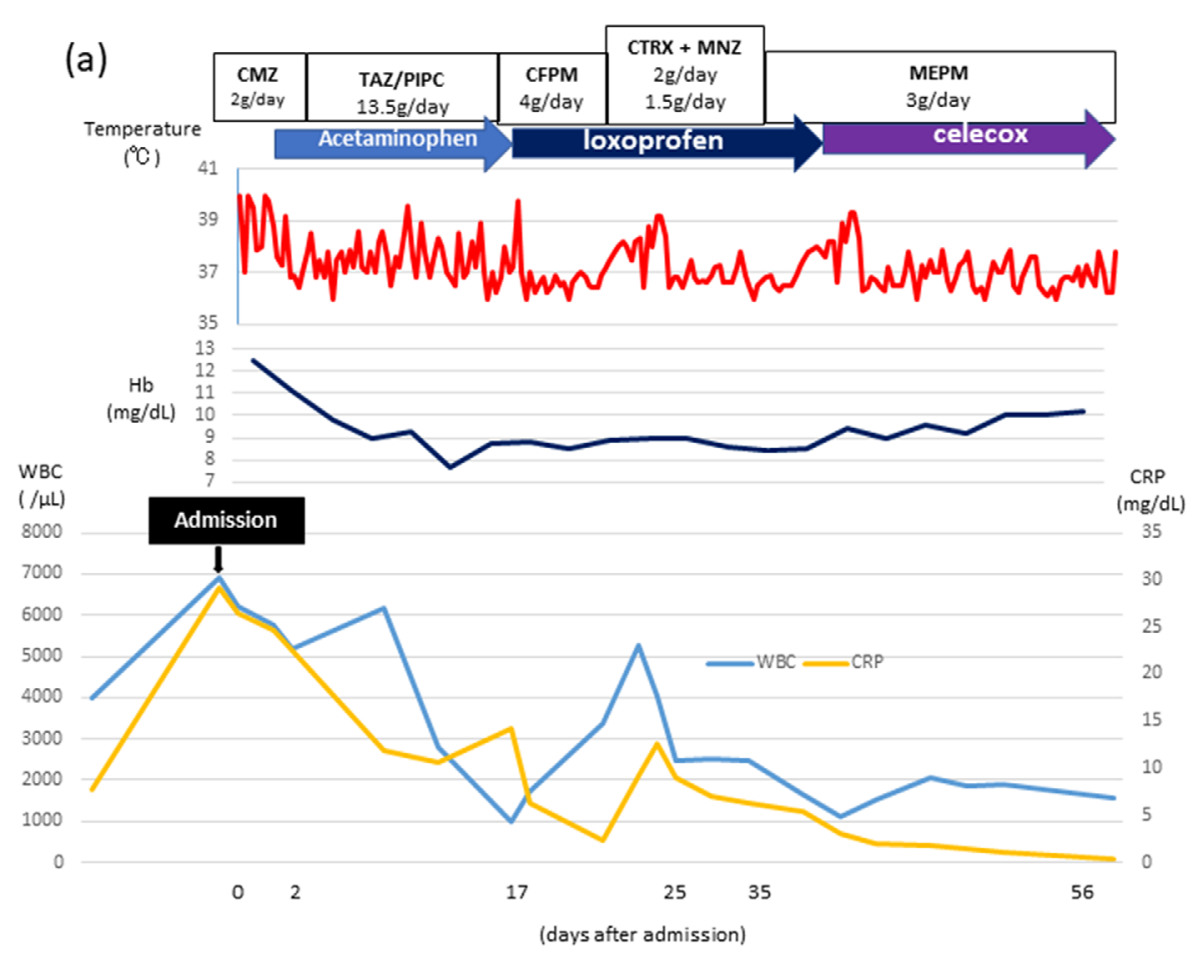

(b)

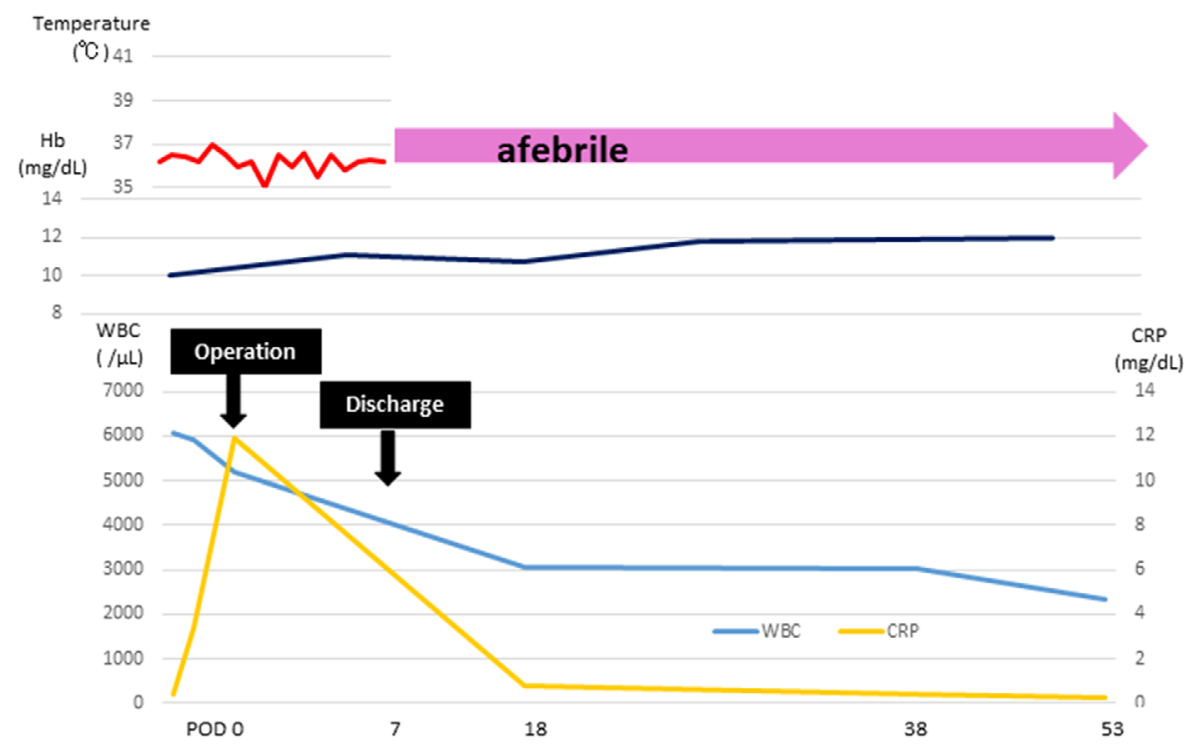

Figure 3. Clinical course of the patient. The patient received several antibiotics and antipyretics and her fever declined to $<38^{\circ} \mathrm{C}$, but the symptoms recurred after treatment discontinuation (a). The fever continued for about 3 months. Both hemangiomas were resected laparoscopically. On day 4 after the operation, the fever decreased to $36^{\circ} \mathrm{C}$, and was absent thereafter (b). The patient was discharged 7 days after the operation and was afebrile for 2 months. WBC: white blood cell, CRP: Creactive protein, Hb: hemoglobin, CMZ: cefmetazole sodium, TAZ/PIPC: tazobactam/piperacillin, CFPM: cefepime dihydrochloride hydrate, CTRX+MNZ: ceftriaxone+metronidazole, MEPM: meropenem hydrate

(CRP) $29.24 \mathrm{mg} / \mathrm{dL}$ were increased. Des- $\gamma$ carboxyprothrombin (DCP) was slightly elevated (72 mAU/ $\mathrm{mL}$ ), other tumor markers were not elevated. Plain computed tomography (CT) of the abdomen showed slightly high intensity inside the mass (Fig. 1a, circle). Abdominal contrast CT revealed hepatic masses $10 \mathrm{~cm}$ in size on liver S8/7 (Fig. 1b, arrow) and S3/2 (Fig. 1c, arrow) with pro- longed enhancement suggesting hepatic hemangiomas. Imaging examination revealed no other abnormalities. Masses in S8/7 (Fig. 2a, b) and S3/2 (Fig. 2c, d) were seen as lowintensity masses by $\mathrm{T} 1$ weighted-enhanced magnetic resonance imaging (MRI) and revealed peripheral nodular enhancement after gadolinium ethoxybenzyl diethlenetriamine pentaacetic acid (God-EOB-DTPA) administration. It con- 
a)
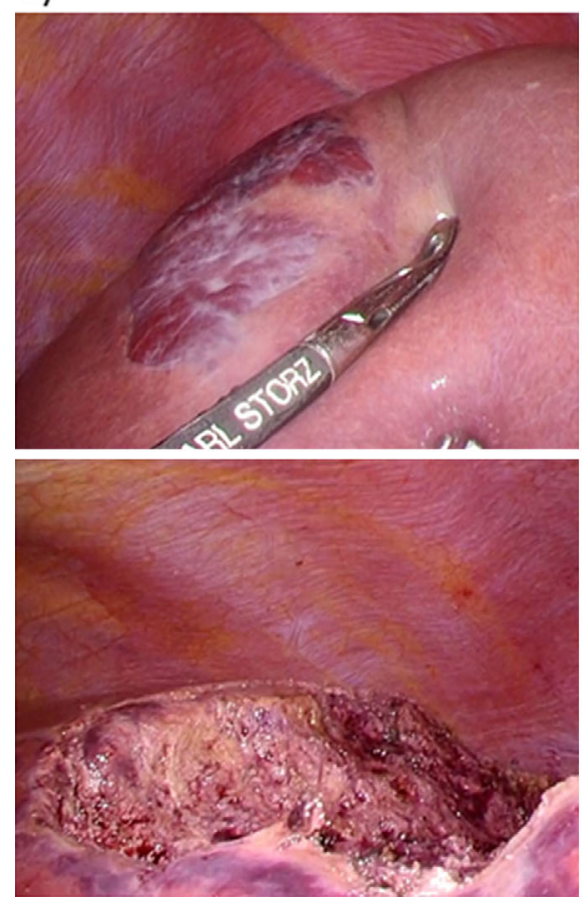

b)
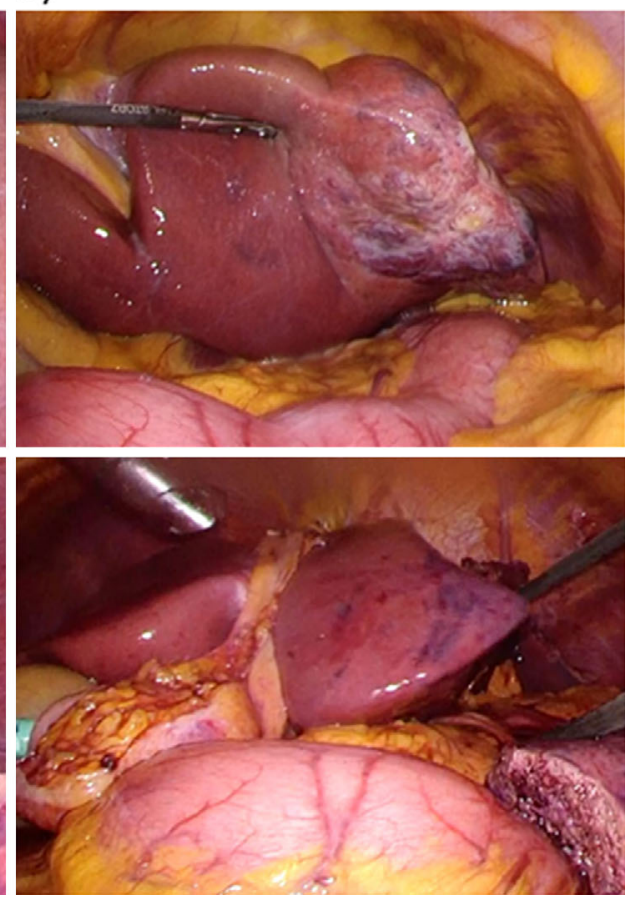

Figure 4. Laparoscopic findings of the liver a) left and b) right lobe. Laparoscopic findings of the liver showed hemangioma on the surface of the left lobe (a, S8/7) and (b, S3/2). Hepatic resection of both hemangiomas was performed. The figures on the right show the liver after hepatectomy $(a, b)$.

sists of fine honeycomb-like septum inside of hemangioma in $\mathrm{S} 8 / 7$. Hepatic bleeding was suspected inside the mass in $\mathrm{S} 3 / 2$ on a T2 weighted-enhanced image after God-EOBDTPA enhancement (Fig. 2e). Gadolinium scintigraphy showed slightly positive in the right lobe (Fig. 2f). All cultures were negative and no infections were found in blood, urine, or cerebrospinal fluid. There was no progression of dry mouth, dry eye, or salivary gland swelling and no exacerbation of Sjögren syndrome was evident. Fever was reduced to $<38^{\circ} \mathrm{C}\left(100.4^{\circ} \mathrm{F}\right)$ by administration of antibacterial and antipyretics, and serum levels of CRP gradually decreased (Fig. 3a). However, the symptoms recurred after treatment discontinuation. The fever continued for about 3 months. Because hepatic hemangiomas and their bleeding were considered the cause of fever, these were resected laparoscopically for diagnostic treatment. Laparoscopic findings of the liver showed hemangiomas on the surface of the right (S8/7) (Fig. 4a) and left (S3/2) lobes (Fig. 4b). The cross-sections showed bleeding inside the $\mathrm{S} 3 / 2$ mass (Fig. 5b), but not in S8/7 mass (Fig. 5a). The pathological diagnosis was cavernous hemangiomas (Fig. 5c, d, black arrows), and there were no malignant findings, but hematoma was observed inside the $\mathrm{S} 3 / 2$ hemangioma (Fig. 5d, red arrows). Immunohistochemically, positive staining for IL-1 $\beta$ and IL-6 was detected in sinusoidal endothelial cells in S8 hemangioma (Fig. 5e, g), whereas those were in sinusoidal endothelial cells and inflammatory infiltrates in S3 hemangioma (Fig. 5f, h). On day 4 after the operation, the fever decreased to $36^{\circ} \mathrm{C}\left(96.8^{\circ} \mathrm{F}\right)$, and no fever was observed thereafter (Fig. 3b). CRP levels also declined after the op- eration. The patient was discharged 7 days after the operation and was afebrile for 2 months.

\section{Discussion}

We experienced a case of giant hepatic hemangioma with fever due to spontaneous bleeding inside the hemangioma forming a hepatoma. Laparoscopic hepatic resection was performed as a diagnostic treatment, and the patient was completely cured. For hepatic hemangiomas, a maximum diameter of $\geq 10 \mathrm{~cm}$, intra-tumoral hemorrhage, and tumor rupture, as well as hematomas causing fever, are indicated for surgical resection.

Hepatic hemangiomas are sevenfold more frequent in females than males (5). Associations with pregnancy and sex hormones are suspected $(6,10)$. Glinkova et al. (6) reported that age at first menstrual period is inversely associated, and age at menopause is positively correlated, with the number of hemangiomas. In addition, in a previous study, hemangiomas grew by $0.5-6.0 \mathrm{~cm}$ over 2-17 years in 12/94 cases $(12.7 \%)$, and 5 cases received hormone therapy whereas tumor tissues were negative for estrogen receptors and progesterone receptors (10). In our case, the patient had no history of hormonal therapy and was menopausal, suggesting that estrogen was not linked to the hemangioma. In the cases with hepatic hemangioma which caused a prolonged fever, the seven females and 4 males were reported (Table 2). Although, we did not know why the proportion of male increased, suspected to be a cause other than hormones.

Hepatic hemangioma is generally asymptomatic. Sympto- 
a)

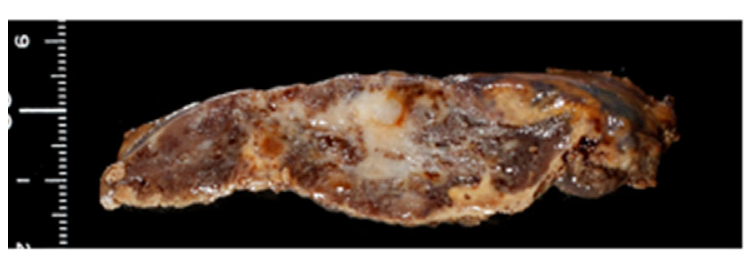

c)

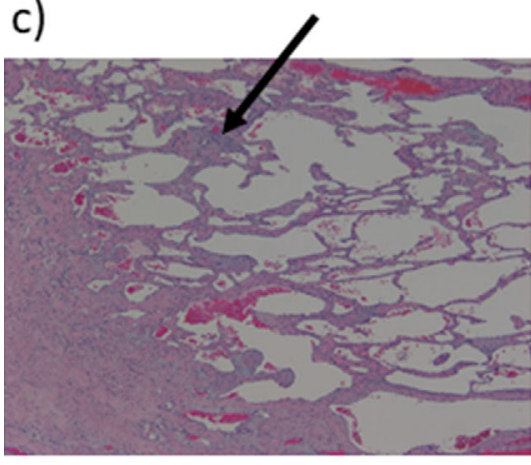

e)

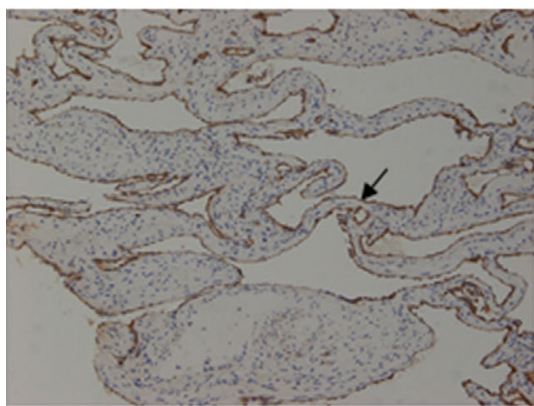

g)

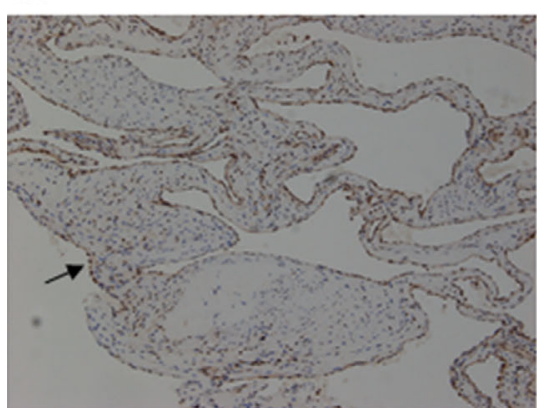

d)

f)

h) b)
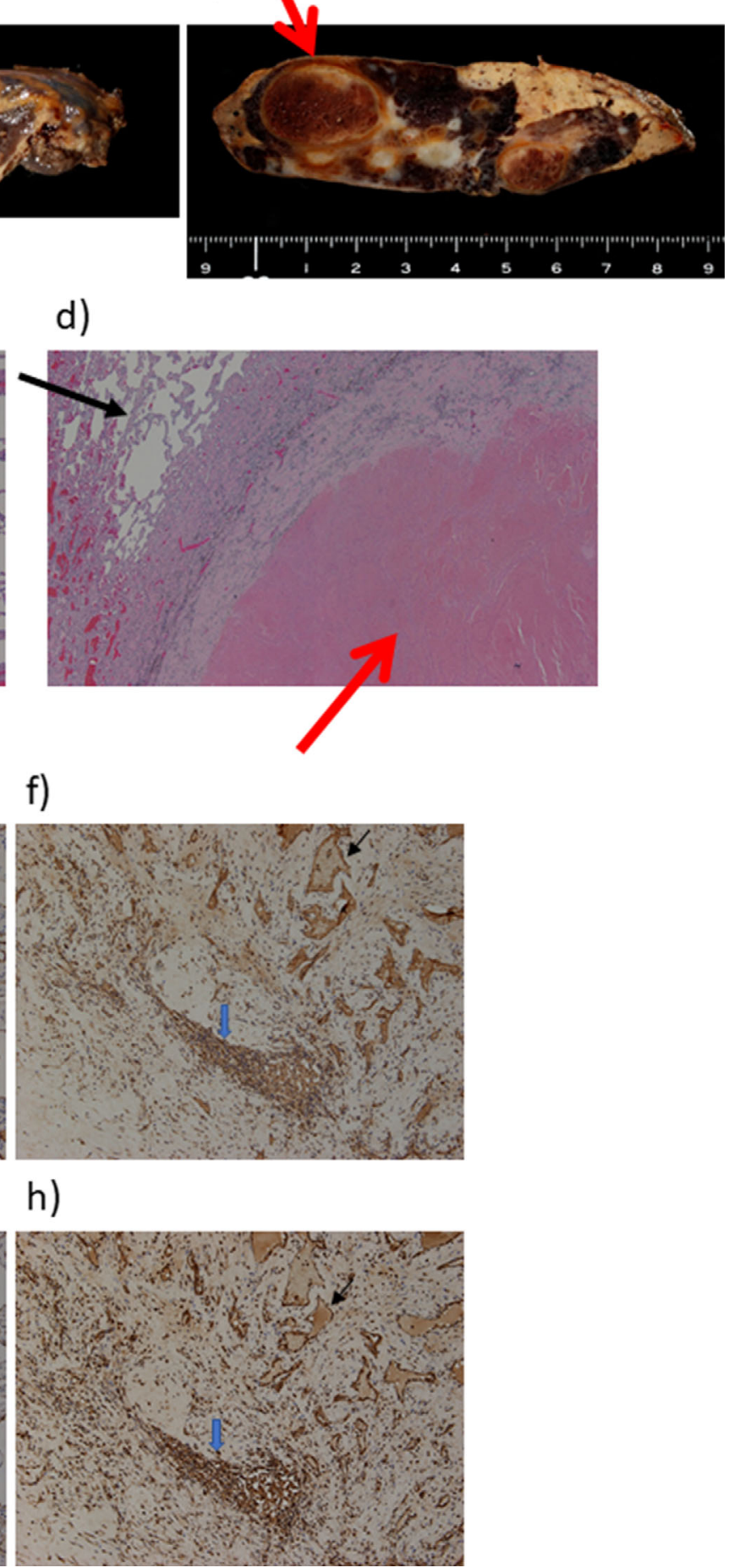

Figure 5. Pathological findings of the liver. a), b) Macroscopic and c), d) microscopic findings of the liver; Hematoxylin and Eosin staining. e), f) IL-1 $\beta$ and g), h) IL-6 staining. Cross-sections of the masses in S8/7 (a) and S3/2 (b) revealed areas of hematoma in a S3/2 hemangioma (b, d, red arrow). Both were confirmed pathologically to be cavernous hemangiomas (c, d, black arrows). Immunohistochemically, positive staining for IL-1 $\beta$ and IL-6 was detected in sinusoidal endothelial cells (black arrow) in $\mathbf{S 8}$ hemangioma (e, g), whereas those were in sinusoidal endothelial cells (black arrow) and inflammatory infiltrates (blue arrow) in S3 hemangioma (f, h). IL: interleukin

matic (size increase, pain, and Kasabach-Merritt syndrome) hepatic hemangiomas are indicated for surgical treatment due to exposure of platelets to subendothelial collagen (11-13). In a nationwide survey in Japan, surgical resec- tion was indicated in patients with $>5 \mathrm{~cm}$ hemangiomas when a malignant tumor could not be ruled out (14). In our case, because we applied several antibiotics and antipyretics, the effect was transient. We attempted to use gallium scin- 
Table 1. Laboratory Parameters upon Admission to Our Hospital.

\begin{tabular}{|c|c|c|c|c|c|}
\hline \multicolumn{2}{|l|}{ Hematology } & \multicolumn{2}{|l|}{ Tumor markers } & \multicolumn{2}{|c|}{ Cerebrospinal fluid test } \\
\hline WBC & $6,900 / \mu \mathrm{L}$ & AFP & $2 \mathrm{U} / \mathrm{mL}$ & Cell counts & $1 / \mu \mathrm{L}$ \\
\hline Neut & $89.7 \%$ & CEA & $1.1 \mathrm{ng} / \mathrm{mL}$ & Specific gravity & 1.005 \\
\hline Lymph & $5.8 \%$ & DCP & $72 \mathrm{mAU} / \mathrm{mL}$ & & \\
\hline Mono & $4.5 \%$ & & & & \\
\hline Eos & $0.0 \%$ & Serology & & & \\
\hline Baso & $0.0 \%$ & $\mathrm{IgG}$ & $2,029 \mathrm{mg} / \mathrm{dL}$ & & \\
\hline $\mathrm{RBC}$ & $3.85 \times 10^{6} / \mu \mathrm{L}$ & $\operatorname{IgM}$ & $46 \mathrm{mg} / \mathrm{dL}$ & & \\
\hline $\mathrm{Hb}$ & $11.1 \mathrm{~g} / \mathrm{dL}$ & $\operatorname{Ig} \mathrm{A}$ & $416 \mathrm{mg} / \mathrm{dL}$ & & \\
\hline $\mathrm{Ht}$ & $36.6 \%$ & ANA & 160 & & \\
\hline PLT & $34.1 \times 10^{4} / \mu \mathrm{L}$ & $\mathrm{RF}$ & $9 \mathrm{U} / \mathrm{mL}$ & & \\
\hline & & DNA antibody & $11 \mathrm{IU} / \mathrm{mL}$ & & \\
\hline Biochemistry & & SS-A antibody & $3620 \mathrm{U} / \mathrm{mL}$ & & \\
\hline $\mathrm{TP}$ & $8.3 \mathrm{~g} / \mathrm{dL}$ & SS-B antibody & $333 \mathrm{U} / \mathrm{mL}$ & & \\
\hline ALB & $3.3 \mathrm{~g} / \mathrm{dL}$ & Scl-70 antibody & $<1.0 \mathrm{U} / \mathrm{mL}$ & & \\
\hline T-BIL & $0.9 \mathrm{mg} / \mathrm{dL}$ & SM antibody & $4.3 \mathrm{U} / \mathrm{mL}$ & & \\
\hline AST & $27 \mathrm{U} / \mathrm{L}$ & MPO-ANCA & $<1.0 \mathrm{U} / \mathrm{mL}$ & & \\
\hline ALT & $20 \mathrm{U} / \mathrm{L}$ & PR3-ANCA & $1.1 \mathrm{U} / \mathrm{mL}$ & & \\
\hline ALP & $245 \mathrm{U} / \mathrm{L}$ & & & & \\
\hline GGT & $78 \mathrm{U} / \mathrm{L}$ & Hepatitis virus & & & \\
\hline LDH & $173 \mathrm{U} / \mathrm{L}$ & HBs antigen & $(-)<0.02 \mathrm{IU} / \mathrm{mL}$ & & \\
\hline BUN & $11.4 \mathrm{mg} / \mathrm{dL}$ & HBs antibody & $(-)<1.0 \mathrm{IU} / \mathrm{mL}$ & & \\
\hline $\mathrm{Cr}$ & $0.75 \mathrm{mg} / \mathrm{dL}$ & HBc antibody & (-) S/CO & & \\
\hline $\mathrm{Na}$ & $136 \mathrm{mEq} / \mathrm{L}$ & HCV antibody & (-) $\mathrm{COI}$ & & \\
\hline K & $3.4 \mathrm{mEq} / \mathrm{L}$ & CMV-IgM & $0.18(-)$ & & \\
\hline $\mathrm{Cl}$ & $97 \mathrm{mEq} / \mathrm{L}$ & CMV-IgG & $2.4(+-)$ & & \\
\hline Uric acid & $3.5 \mathrm{mg} / \mathrm{dL}$ & EBV-VCA-IgM & $<40(-)$ & & \\
\hline Ferritin & $516 \mathrm{ng} / \mathrm{dL}$ & EBV-VCA-IgG & $40(-)$ & & \\
\hline $\mathrm{NH}_{3}$ & $132 \mu \mathrm{g} / \mathrm{dL}$ & EBV-EBNA & 40 & & \\
\hline CRP & $29.24 \mathrm{mg} / \mathrm{dL}$ & VZV-IgM & $0.33(-)$ & & \\
\hline & & VZV-IgG & $12.2(+)$ & & \\
\hline Coagulation & & HSV-IgM & $<4(-)$ & & \\
\hline PT-INR & 1.21 & HSV-IgG & $3.2(+-)$ & & \\
\hline PT\% & $69.4 \%$ & T-SPOT & $(-)$ & & \\
\hline PT control & $11.3 \mathrm{sec}$ & $\beta$-D gulcan & $22.3 \mathrm{pg} / \mathrm{mL}$ & & \\
\hline PT & $13.6 \mathrm{sec}$ & Cryptococcus antigen & $(-)$ & & \\
\hline APTT control & $27.8 \mathrm{sec}$ & Aspergillus antigen & $(-)$ & & \\
\hline APTT & $30.2 \mathrm{sec}$ & & & & \\
\hline FDP & $9.7 \mu \mathrm{g} / \mathrm{mL}$ & Urine & & & \\
\hline D-dimer & $3.4 \mu \mathrm{g} / \mathrm{mL}$ & WBC & $(-)$ & & \\
\hline fibrinogen & $766 \mathrm{mg} / \mathrm{dL}$ & & & & \\
\hline
\end{tabular}

WBC: white blood cell, RBC: red blood cell, Hb: hemoglobin, Lymph: lymphocyte, Mono: monocyte, Eos: eosinophil granulocyte, Baso: basophil leucocyte, Ht: hematocrit, PLT: platelet, TP: total protein, ALB: albumin, T-BIL: total bilirubin, AST: aspartate aminotransferase, ALT: alanine aminotransferase, ALP: alkaline phosphatase, GGT: gamma-glutamyl transferase, LDH: lactate dehydrogenase, BUN: blood urea nitrogen, Cr: creatinine, Na: sodium, $\mathrm{K}$ : potassium, $\mathrm{Cl}$ : chloride, $\mathrm{NH}_{3}$ : ammonia, CRP: C-reactive protein, PT-INR: international normalized ratio of prothrombin time, PT: prothrombin time, APTT: activated partial thromboplastin time, FDP: fibrin degradation product, AFP: $\alpha$-fetoprotein, CEA: carcinoembryonic antigen, DCP: des-gamma-carboxy prothrombin, IgG: immunoglobulin G, IgM: immunoglobulin M, IgA: immunoglobulin A, ANA: antinuclear antigen, RF: rheumatic factor, DNA antibody: anti-native DNA antibody, SS-A antibody: anti-Sjögren syndrome-A antibody, SS-B antibody: antiSjögren syndrome-B antibody, Scl-70 antibody: anti-scleroderma antibody, SM antibody: anti-SM antibody, MPOANCA: myeloperoxidase antineutrophil cytoplasmic antibody, PR3-ANCA: proteinase 3 antineutrophil cytoplasmic antibody, HBs antigen: hepatitis B surface antigen, $\mathrm{HBc}$ antibody: hepatitis B core antibody, HCV: hepatitis C virus, CMV: cytomegalovirus, EBV-VCA: Epstein-Barr virus-viral capsid antigen antibody, EBV-EBNA: EB virus nuclear antigen, VZV: Varicella and herpes zoster vaccines, HSV: herpes simplex virus

tigraphy to identify the cause of fever, and it was slightly positive for the right mass.

Hepatic hemangioma is a very rare cause of FUO. Al- Therefore, we suspected hemangioma as a source of fever.

though collagen diseases can cause FUO, there was no evidence of deterioration of Sjögren syndrome in this case. 
Table 2. Cases of Hepatic Hemangioma Causing FUO.

\begin{tabular}{|c|c|c|c|c|c|c|c|c|c|c|}
\hline Author & $\begin{array}{l}\text { Published } \\
\text { year }\end{array}$ & Age & Sex & Symptoms & $\begin{array}{l}\text { Duration } \\
\text { of fever }\end{array}$ & $\begin{array}{l}\text { Tumor } \\
\text { size }\end{array}$ & $\begin{array}{l}\text { Cause of } \\
\text { fever }\end{array}$ & Complications & Treatment & Outcome \\
\hline $\begin{array}{l}\text { Fenster } \\
\text { et al. }{ }^{15}\end{array}$ & 1978 & 43 & $\mathrm{~F}$ & $\begin{array}{l}\text { Malaise, myalgias, } \\
\text { progressive weakness, } \\
\text { shaking chills and fever with } \\
\text { profuse night sweats. }\end{array}$ & $8 \mathrm{Mo}$ & $\begin{array}{l}\text { Entire } \\
\text { right lobe }\end{array}$ & $\begin{array}{c}\text { Internal } \\
\text { Hemorrhage }\end{array}$ & - & $\begin{array}{l}\text { Right hepatic } \\
\text { lobectomy/ } \\
\text { prednisone }\end{array}$ & Cured \\
\hline $\begin{array}{l}\text { Hopkins } \\
\text { et al. }{ }^{17}\end{array}$ & 1990 & 46 & $\mathrm{~F}$ & $\begin{array}{l}\text { Right upper quadrant } \\
\text { abdominal pain, fever, chills, } \\
\text { night swears, anorexia, } \\
\text { cough }\end{array}$ & $1 \mathrm{Mo}$ & $18 \times 14 \mathrm{~cm}$ & Thrombosis & - & $\begin{array}{l}\text { Right hepatic } \\
\text { lobectomy }\end{array}$ & Cured \\
\hline \multirow[t]{2}{*}{$\begin{array}{l}\text { Pateron } \\
\text { et al. } .^{21}\end{array}$} & 1991 & 47 & M & $\begin{array}{c}\text { Fatigue, weight loss, } \\
\text { anorexia, and fluctuating } \\
\text { fever }\end{array}$ & $4 \mathrm{Mo}$ & $\begin{array}{l}\text { Giant, } \\
\text { right lobe }\end{array}$ & $\begin{array}{l}\text { Thrombosis } \\
\text { and necrosis }\end{array}$ & - & $\begin{array}{c}\text { Right } \\
\text { hepatectomy }\end{array}$ & Cured \\
\hline & & 44 & M & $\begin{array}{l}\text { Epigastric pain, weight loss } \\
\text { of } 8 \mathrm{~kg} \text {, and night sweats. }\end{array}$ & $5 \mathrm{Mo}$ & $\begin{array}{l}\text { Giant, left } \\
\text { lobe }\end{array}$ & $\begin{array}{l}\text { Thrombosis } \\
\text { and necrosis }\end{array}$ & - & $\begin{array}{c}\text { Left } \\
\text { hepatectomy }\end{array}$ & Cured \\
\hline $\mathrm{Hao}^{18}$ & 2017 & 52 & $\mathrm{~F}$ & Fever & $1 \mathrm{Mo}$ & $15 \mathrm{~cm}$ & $\begin{array}{c}\text { Internal } \\
\text { hemorrhage }\end{array}$ & - & $\begin{array}{l}\text { Interventional } \\
\text { therapy and } \\
\text { resection }\end{array}$ & Cured \\
\hline $\begin{array}{l}\text { Pandit } \\
\text { et al. }\end{array}$ & 2018 & 49 & $\mathrm{~F}$ & Fever & 3 Mo & $15 \times 11 \mathrm{~cm}$ & Necrosis & - & $\begin{array}{l}\text { Laparoscopic- } \\
\text { assisted left } \\
\text { lateral } \\
\text { segmentectomy }\end{array}$ & Cured \\
\hline $\begin{array}{l}\text { Liu } \\
\text { et al. }{ }^{19}\end{array}$ & 2018 & 33 & M & Fever & $2 \mathrm{Mo}$ & $20 \mathrm{~cm}$ & Necrosis & - & $\begin{array}{l}\text { Right } \\
\text { trisectionectomy }\end{array}$ & Cured \\
\hline $\begin{array}{l}\text { Desai } \\
\text { et al. }{ }^{4}\end{array}$ & 2020 & 38 & $\mathrm{~F}$ & Fever & $1 \mathrm{Mo}$ & $\begin{array}{l}\text { Right lobe } \\
\text { of the liver }\end{array}$ & $\begin{array}{l}\text { Hemorrhage } \\
\text { and } \\
\text { thrombus }\end{array}$ & - & $\begin{array}{l}\text { Right } \\
\text { hepatectomy }\end{array}$ & Cured \\
\hline $\begin{array}{l}\text { Wang } \\
\text { et al. }\end{array}$ & 2020 & 59 & $\mathrm{~F}$ & $\begin{array}{l}\text { Fever, night sweat, chills, } \\
\text { weight loss }\end{array}$ & $6 \mathrm{Mo}$ & $\begin{array}{l}9 \times 6.6 \times 10 \\
\mathrm{~cm}\end{array}$ & $\begin{array}{l}\text { Infected } \\
\text { necrosis and } \\
\text { internal } \\
\text { hemorrhage }\end{array}$ & - & $\begin{array}{l}\text { Hepatic } \\
\text { resection }\end{array}$ & Cured \\
\hline Our case & & 53 & $\mathrm{~F}$ & Fever & 3 Mo & $10 \mathrm{~cm}$ & $\begin{array}{c}\text { Internal } \\
\text { hemorrhage } \\
\text { and } \\
\text { hematoma }\end{array}$ & $\begin{array}{l}\text { Sjögren } \\
\text { syndrome }\end{array}$ & $\begin{array}{l}\text { Hepatic } \\
\text { resection }\end{array}$ & Cured \\
\hline
\end{tabular}

ALD: alcoholic liver disease, F: female, FUO: fever of unknown origin, M: male, Mo: months

Fenster et al. (15) described a 43-year-old female with a huge hepatic hemangioma presenting with fever for 8 months and treated with prednisone. However, fever was not resolved, and right hepatic lobectomy was required. By contrast, Lee et al. (16) reported a 37-year-old female with a 50 $\mathrm{mm}$ hemangioma and fever. Fever improved over 28 days with observation. Most cases resolved after $<1$ month by resection $(4,16-20)$, whereas some experienced $>3$ months of fever (15, 21-24) (Table 2). The possibility of hepatic hemangioma with necrosis or bleeding may have caused fever. Among 11 cases, intrahepatic hemorrhage, necrosis, and thrombus were observed in 5 cases $(45.5 \%), 5$ cases $(45.5 \%)$, and 4 cases $(36.4 \%)$, respectively. Stimulated hepatic macrophages (Kupffer cells) release cytokines, which play a role in host defense against antigens. The release of immune mediators by sinusoidal lining cells such as Kupffer cells lining the hemangioma may induce fever. Moreover, these cells release IL- 1 and IL-6 may contribute to the hepatic inflammatory response in animal models (25). Although, we did not measure those markers in our case, im- munohistochemically, positive staining for IL-1 $\beta$ and IL-6 was detected in sinusoidal endothelial cells and inflammatory infiltrates and those might be associated with a prolonged fever. The patient's anemia gradually developed and intra-hemorrhage was suspected in the left mass. CT and MRI findings and gallium scintigraphy were inconsistent; therefore, we decided to resect both hemangiomas surgically for diagnostic treatment. Active small bleeding forming hematoma (S3/2) may result in continuous fever for $>3$ months.

In conclusion, it should be noted that giant, bleeding hepatic hemangiomas can cause prolonged fever and are indicated for surgical resection. Because hematoma or necrosis can cause FUO, detecting the lesion is important for deciding whether to perform resection.

\section{The authors state that they have no Conflict of Interest (COI).}

\section{Human and animal rights}

All procedures were performed in accordance with the ethical 
standards laid down in the 1964 Declaration of Helsinki and its later amendments.

\section{Informed consent}

Informed consent was obtained from the patient for the publication of this case study.

\section{References}

1. Reddy KR, Kligerman S, Levi J, Livingstone A, Molina E, Franceschi D, et al. Benign and solid tumors of the liver: relationship to sex, age, size of tumors, and outcome. Am Surg 67: 173178, 2001.

2. EASL Clinical Practice Guidelines on the management of benign liver tumours. J Hepatol 65: 386-398, 2016.

3. Kim GE, Thung SN, Tsui WM, Ferrell LD. Hepatic cavernous hemangioma: underrecognized associated histologic features. Liver Int 26: 334-338, 2006.

4. Desai G, Budkule D, Pande P, Wagle P. Pyrexia of Unknown Origin: An Atypical Presentation of Hepatic Hemangioma. Surg J (N Y) 6: e180-e84, 2020.

5. Gandolfi L, Leo P, Solmi L, Vitelli E, Verros G, Colecchia A. Natural history of hepatic haemangiomas: clinical and ultrasound study. Gut 32: 677-680, 1991.

6. Glinkova V, Shevah O, Boaz M, Levine A, Shirin H. Hepatic haemangiomas: possible association with female sex hormones. Gut 53: 1352-1355, 2004.

7. Nelson RC, Chezmar JL. Diagnostic approach to hepatic hemangiomas. Radiology 176: 11-13, 1990.

8. Petersdorf RG, Beeson PB. Fever of unexplained origin: report on 100 cases. Medicine (Baltimore) 40: 1-30, 1961.

9. Schumacker HB. J. Hemangioma of the liver: discussion of symptomatology and report of patient treated by operation. Surgery 11: 209-222, 1942

10. Saegusa T, Ito K, Oba N, Matsuda M, Kojima K, Tohyama K, et al. Enlargement of multiple cavernous hemangioma of the liver in association with pregnancy. Intern Med 34: 207-211, 1995.

11. Toro A, Mahfouz AE, Ardiri A, Malaguarnera M, Malaguarnera G, Loria F, et al. What is changing in indications and treatment of hepatic hemangiomas. A review. Ann Hepatol 13: 327-339, 2014.

12. Miura JT, Amini A, Schmocker R, Nichols S, Sukato D, Winslow ER, et al. Surgical management of hepatic hemangiomas: a multiinstitutional experience. HPB (Oxford) 16: 924-928, 2014.
13. Hall GW. Kasabach-Merritt syndrome: pathogenesis and management. Br J Haematol 112: 851-862, 2001.

14. Sakamoto Y, Kokudo N, Watadani T, Shibahara J, Yamamoto M, Yamaue $\mathrm{H}$, et al. Proposal of size-based surgical indication criteria for liver hemangioma based on a nationwide survey in Japan. J Hepatobiliary Pancreat Sci 24: 417-425, 2017.

15. Fenster LF, Freeny PC, Beebe HG. Case reports. Cavernous hemangioma of the liver presenting with fever. Successful treatment with prednisone. West J Med 129: 138-140, 1978.

16. Lee CW, Chung YH, Lee GC, Kim JY, Lee JS. A case of giant hemangioma of the liver presenting with fever of unknown origin. J Korean Med Sci 9: 200-204, 1994.

17. Hopkins BR. Hepatic Hemangioma: An Unusual Cause of Fever of Unknown Origin. 4: 227-229, 1990.

18. Hao F, Yang X, Tian Y, Wang W, Ge M. Spontaneous internal hemorrhage of a giant hepatic hemangioma: A case report. Medicine (Baltimore) 96: e8702, 2017.

19. Liu X, Yang Z, Tan H, Zhou W, Su Y. Fever of Unknown Origin Caused by Giant Hepatic Hemangioma. J Gastrointest Surg 22: 366-367, 2018.

20. Yang YG, Chen WF, Mai WH, Li XF, Zhou HL, Liu LJ, et al. Spontaneous intracapsular hemorrhage of a giant hepatic cavernous hemangioma: a rare case report and literature review. BMC Gastroenterol 21: 84, 2021.

21. Pateron D, Babany G, Belghiti J, Hadengue A, Menu Y, Flejou JF, et al. Giant hemangioma of the liver with pain, fever, and abnormal liver tests. Report of two cases. Dig Dis Sci 36: 524-527, 1991.

22. Khalid M, Ahmad M, Jain A, Rizvi I. Atypical giant haemangioma of liver with systemic inflammatory manifestations. BMJ Case Rep 2013: 2013.

23. Pandit N, Awale L, Chaudhary S, Jaiswal LS. Fever of unknown origin: a rare presentation of giant hepatic hemangioma. J Surg Case Rep 2018: rjy143, 2018.

24. Wang A, Chen H, Huang Z, Tang H, Shi H, Wen J, et al. Spontaneous internal hemorrhage of a giant hepatic hemangioma with infection: a case report and literature review. J Int Med Res 48: 300060520976474, 2020.

25. Feder LS, Todaro JA, Laskin DL. Characterization of interleukin-1 and interleukin-6 production by hepatic endothelial cells and macrophages. J Leukoc Biol 53: 126-132, 1993.

The Internal Medicine is an Open Access journal distributed under the Creative Commons Attribution-NonCommercial-NoDerivatives 4.0 International License. To view the details of this license, please visit (https://creativecommons.org/licenses/ by-nc-nd/4.0/).

(C) The Japanese Society of Internal Medicine Intern Med Advance Publication 